\title{
Spatio-Temporal Variation of Atmospheric Nutrient Deposition in Different Land Uses/Covers around Lake Kivu
}

\author{
Mashimango Bagalwa ${ }^{1,2,3}{ }^{*}$, Jackson Gilbert Mwanjalolo Majaliwa ${ }^{4}$, Harvey Bootsma5, \\ Katcho Karume ${ }^{3,6}$, Sarah Akello1, Frank Kansiime1 \\ ${ }^{1}$ College of Agricultural and Environmental Sciences, Makerere University, Kampala, Uganda \\ ${ }^{2}$ Department of Biology, Centre de Recherche en Sciences Naturelles (CRSN/Lwiro), Bukavu, Democratic Republic of Congo \\ ${ }^{3}$ Faculté des Sciences Agronomique et Environnement, Université Evangélique en Afrique, Bukavu, Democratic Republic of Congo \\ ${ }^{4}$ Regional University Forum for Capacity Building in Agriculture (RUFORUM), Kampala, Uganda \\ ${ }^{5}$ School of Freshwater Sciences, University of Wisconsin-Milwaukee, Milwaukee, USA \\ ${ }^{6}$ Observatoire Volcanologique de Goma, Department of Geochemistry and Environment, Goma, Democratic Republic of Congo \\ Email: *mashibagalwa@gmail.com
}

How to cite this paper: Bagalwa, M., Majaliwa, J.G.M., Bootsma, H., Karume, K., Akello, S. and Kansiime, F. (2021) Spatio-Temporal Variation of Atmospheric Nutrient Deposition in Different Land Uses/Covers around Lake Kivu. Journal of Water Resource and Protection, 13, 699-725. https://doi.org/10.4236/jwarp.2021.139037

Received: August 8, 2021

Accepted: September 24, 2021

Published: September 27, 2021

Copyright $\odot 2021$ by author(s) and Scientific Research Publishing Inc. This work is licensed under the Creative Commons Attribution International License (CC BY 4.0).

http://creativecommons.org/licenses/by/4.0/

\begin{abstract}
Atmospheric deposition of nutrients, particularly nitrogen and phosphorus has the capacity to significantly affect the productivity and biogeochemistry of aquatic ecosystems. The objective of this study was to assess the impact of land use/cover types on the atmospheric deposition of nutrients around Lake Kivu. Dry and wet atmospheric deposition samples were collected from four different land use/cover types (forest, wetland, agricultural and urbanized area) at four stations (Goma, Lwiro, Bukavu and Iko) around the Lake Kivu basin. The highest annual loading of dry total phosphorus (TP) was recorded at a station located in an urban area at Goma $\left(4.4 \pm 3.9 \mu \mathrm{mol} / \mathrm{m}^{2} / \mathrm{yr}\right)$ and the highest dry deposition of total nitrogen (TN) was recorded at Iko (84.5 \pm 41.2 $\left.\mu \mathrm{mol} / \mathrm{m}^{2} / \mathrm{yr}\right)$. High wet TP and TN were at Bukavu $\left(0.7 \pm 1.1 \mu \mathrm{mol} / \mathrm{m}^{2} / \mathrm{yr}\right)$ and Iko $\left(21.7 \pm 34.7 \mu \mathrm{mol} / \mathrm{m}^{2} / \mathrm{yr}\right)$ respectively. High dry TP loads were recorded in the forest area of Goma and the highest dry TN at Lwiro. High wet TP loads were record in agriculture at Goma and high values of wet TN in agriculture at Iko. Phosphorus and nitrogen deposition rates around Lake Kivu were similar to those reported for other African lakes. The highest rate of TP was recorded mainly in the forest area for dry deposition while high TN was recorded in all types of land use/cover in the basin. This study found out that forest traps high concentration of nutrient than other land uses/covers.
\end{abstract}

\section{Keywords}

Atmospheric Nutrients Deposition, Nitrogen, Phosphorus, Lake Kivu 


\section{Introduction}

Atmospheric deposition is a substantial pathway for the transport of contaminants, resulting in water quality deterioration in different ecosystems across the world. It can affect aquatic ecosystem functions in many ways [1] [2] [3]. Excessive nitrogen and phosphorus inputs are responsible for algal blooms yet decomposition of the algae leads to high oxygen consumption [4]. There is evidence that this may be occurring in the African Great Lakes [5] [6]. Nitrogen $(\mathrm{N})$ and phosphorus $(\mathrm{P})$ are transported into the atmosphere through wind erosion, burning and tillage [7]. Deposition of these particles has been recognized as an important source of nutrients in receiving lakes and other water bodies [8] [9].

Atmospheric composition of nutrients and loads is highly variable [10]. Factors responsible for atmospheric deposition include the type of land use/cover, topography, climate and location. It has been reported that deposition is related to the degree of agricultural activity [11] [12]. McDowell and Sharpley [13] found a significant difference in deposition rates among land uses with more $\mathrm{P}$ and $\mathrm{N}$ deposited on cropland (1.93 $\mathrm{kg} \mathrm{P}$ and $\left.10.71 \mathrm{~kg} \mathrm{~N} \mathrm{ha}^{-1} \cdot \mathrm{yr}^{-1}\right)$ than pasture $\left(1.10 \mathrm{~kg} \mathrm{P}\right.$ and $\left.8.06 \mathrm{~kg} \mathrm{~N} \mathrm{ha}^{-1} \cdot \mathrm{yr}^{-1}\right)$ and woodland $(0.36 \mathrm{~kg} \mathrm{P}$ and $2.33 \mathrm{~kg} \mathrm{~N}$ $\left.\mathrm{ha}^{-1} \cdot \mathrm{yr}^{-1}\right)$. Urbanization contributes to an increase in the sources of pollutants such as $\mathrm{N}$ and P [14] [15] [16]. Large-scale deforestation and biomass burning in the African Great Lakes Region have been reported to influence nutrient deposition from the atmosphere [17] [18]. Tositti et al. [19] observed an increased deposition flux of ${ }^{210} \mathrm{~Pb}$ and ${ }^{137} \mathrm{Cs}$ at sites located at the highest altitudes compared to other altitudes. A study by Guerrieri et al. [20] in the UK demonstrated that climate significantly affected nitrogen availability across Britain.

The importance of atmospheric deposition as a source of nutrients has been well documented in some of these lakes, including Malawi, Tanganyika and Victoria [5] [6] [21]. However, in Lake Kivu, little is known about atmospheric deposition of nutrients [22] [23] [24]. According to Tamatamah et al. [6], deposition of total phosphorus (TP) in rainfall around Lake Victoria is high, compared to other sources. There the high concentration of $\mathrm{P}$ is largely due to deforestation and biomass burning occurring in the African Great Lakes region, which could influence P deposition as observed by other authors [17] [18]. Ahn and James [25] and Shaw et al. [8] argued that dry deposition contributes an equal, if not greater amount of $\mathrm{P}$ than wet deposition. Most of the $\mathrm{P}$ in the atmosphere is in the aerosol form, with little in the gas phase [26]. Mahowald et al. [27] showed that combustion from fossil fuels, biomass burning, volcanoes are the main sources and biofuels represent additional source and contribute small amounts as well. In Lake Kivu, the rate of atmospheric P deposition is high compared to other inputs such as rivers and internal input as shown by Natacha et al. [28].

The effect of atmospheric deposition, particularly $\mathrm{N}$ deposition, in aquatic ecosystems is also well documented and these include environmental effects such as acidification, eutrophication, nutrient imbalances, loss of biodiversity, direct tox- 
icity to plants and negative impacts on human health [29] [30]. Increased rate of $\mathrm{N}$ atmospheric deposition is due to a large number of sources, such as volatilization from animal waste and synthetic fertilizers, biomass burning (including forest fires), losses from soils under native vegetation, agricultural crops, emissions from human excreta and fossil fuel combustion [31] [32]. Both $\mathrm{N}$ and $\mathrm{P}$ are essential to plant nutrients that could affect plant growth [33], biomass allocation, accumulation [34] and quality [35]. Thus, it affects primary productivity [36] and soil carbon exchange [37].

Lake Kivu is the smallest of the African Great Rift lakes, lies on the border between the Democratic Republic of the Congo (DRC) and Rwanda, in the tectonically and volcanically active Western Branch (Albertine Rift) of the East African Rift System [38]. It supports very important fisheries that provide livelihood to hundreds of people and contribute significantly to food supply as a prime source of animal protein [39]. An estimated two million people who live around the lake draw their drinking water from the lake. During the last decade signs of Lake Kivu eutrophication have become more apparent and present significant environmental challenge and danger for the population around the lake [22] [23]. The carbon dioxide and methane content in the lake is reportedly high [40] [41]. In the deep layers of Lake Kivu, high amounts of carbon dioxide $\left(\mathrm{CO}_{2}\right)$ and $\mathrm{CH}_{4}\left(300 \mathrm{Km}^{3}\right.$ and $60 \mathrm{Km}^{3}$, respectively, at $0^{\circ} \mathrm{C}$ and $\left.1 \mathrm{~atm}\right)$ are dissolved [41]. Increased additional carbon and nutrients inputs through atmospheric deposition will certainly exacerbate its instability [40].

In the Great Lakes region of Africa, particularly Lake Kivu, understanding the atmospheric deposition and its variation across land use/cover is important because of the current $\mathrm{CO}_{2}$ and $\mathrm{CH}_{4}$ level in the Lake. The increased transfer of these nutrients into the lake is likely to contribute to creation of $\mathrm{CO}_{2}$ saturation conditions which can trigger a "limnic eruption". Little is known about the influence of urban versus agricultural land use on atmospheric nutrient loads in the region. The present study examined the effect of four main types of land use/cover on atmospheric nutrient deposition in the Lake Kivu region, namely forest, wetland, agriculture and urbanized areas in 4 stations around Lake Kivu basin. The specific objectives of this study were to: 1) assess the temporal trend of atmospheric deposition; 2) assess its spatial variation; and 3) determine the sources of atmospheric nutrient deposition around and within Lake Kivu.

\section{Materials and Methods}

\subsection{Description of Study Area and Sampling Stations}

This study was carried out in Lake Kivu basin on the Democratic Republic Congo side. Lake Kivu is the smallest of the African Great Lakes, located between Rwanda and the Democratic Republic of Congo. It is located at $1463 \mathrm{~m}$ above the sea level, between $1^{\circ} 34.5^{\prime}$ and $2^{\circ} 30^{\prime} \mathrm{S}$ and between $28^{\circ} 50^{\prime}$ and $29^{\circ} 23^{\prime} \mathrm{E}$ (Figure 1 ). Its basin is dominated by steep $(<3 \%)$ hilly topography underlain by sedimentary sandstone and siltstone soils [42] [43]. 


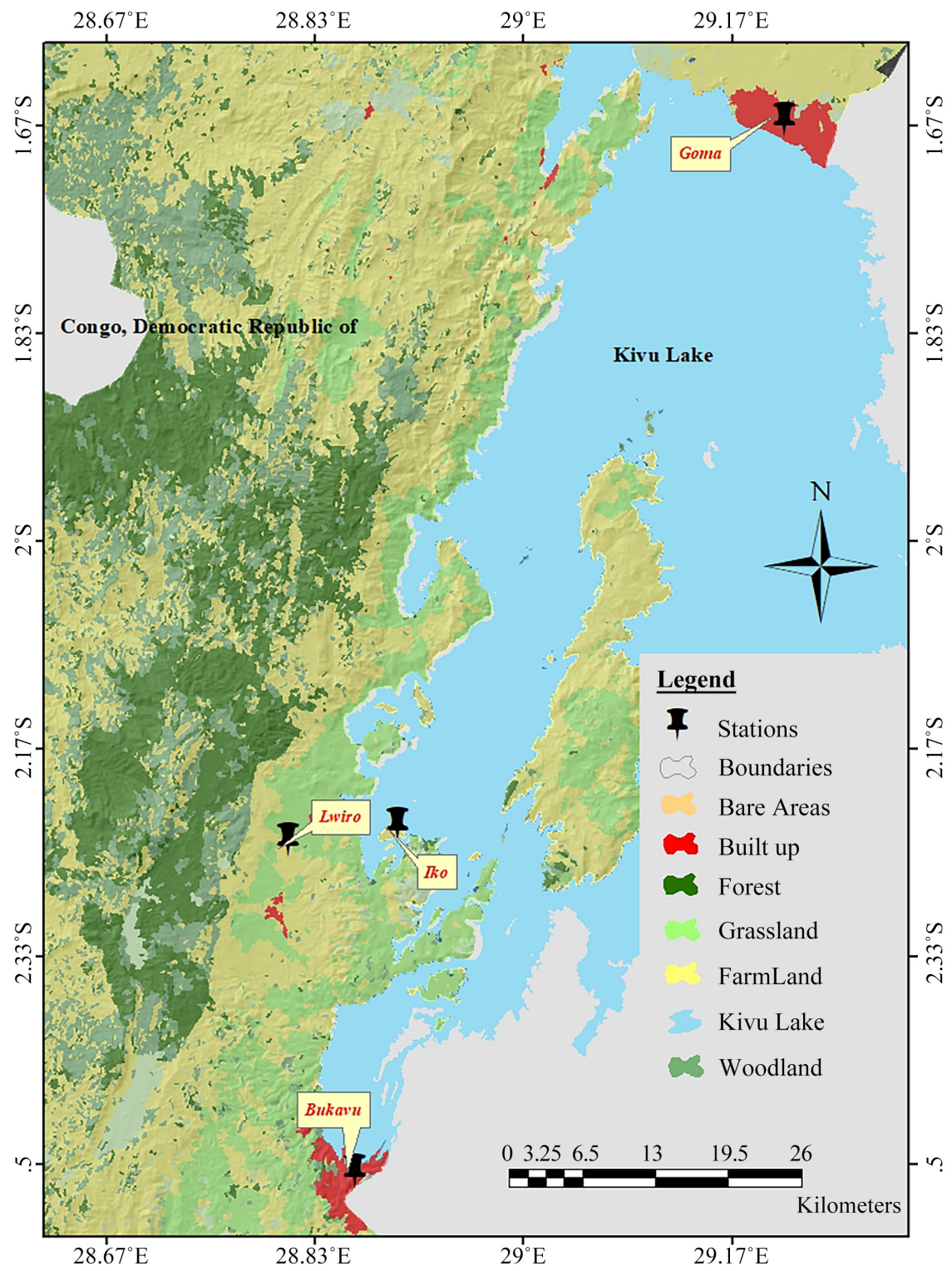

Figure 1. Location of sampling stations within the Lake Kivu basin.

Four sampling stations namely; Goma in the north, Iko within the Lake, Lwiro in the west and Bukavu in the south (Figure 1) were considered in this study and are located on the DRC side of the Lake. The Goma and Bukavu regions are located within town (urban area) in northern and southern part of the lake at $1^{\circ} 41.58^{\prime} \mathrm{S}, 29^{\circ} 22.690^{\prime} \mathrm{E}$ and $2^{\circ} 29.817^{\prime} \mathrm{S}, 28^{\circ} 51.558^{\prime} \mathrm{E}$ respectively. The land use/cover in these areas is mainly characterized by built-up area (settlement) [44]. The areas are densely populated with high transportation activities. Goma is located near the active Virunga volcanoes with high transportation activities. The Lwiro and Iko stations are located at $2^{\circ} 14.228^{\prime} \mathrm{S}, 28^{\circ} 48.441^{\prime} \mathrm{E}$ and $2^{\circ} 14.064^{\prime} \mathrm{S}$, $28^{\circ} 53.555^{\prime} \mathrm{E}$ respectively in rural area. The main land use/cover in these areas is dominated by agriculture land. Lwiro area is located near the Kahuzi Biega National Park forest. These areas are not densely populated. 
The climate in the Lake Kivu basin is tropical, with a bimodal rainfall distribution. The seasons are wet (September-May) and dry (June-August). Annual rainfall is about $1500 \mathrm{~mm}$ in the basin [45]. Rainfall and temperature variations in Lwiro station are presented in the Figure 2.

\subsection{Temporal Trend of Atmospheric Nutrient Deposition under Different Land Uses in the Lake Kivu Basin, DR Congo Side}

At the three stations (Bukavu, Goma and Lwiro), dry and wet atmospheric deposition sampling was carried out in four major land use/cover types, namely forest, agricultural, settlement and wetland, with separate collection stations for each type. However, the fourth station (Iko) had only two land use/cover types (agricultural and forest) from which dry and wet atmospheric deposition sampling was carried out.

Dry atmospheric deposition samples were collected in all the sampling stations on the same day, at intervals of 13 days for a period of 15 months, starting from December 2017 and ended in February 2019. Wet deposition sampling was done on a rain event basis, according to the protocol of Bootsma et al. [5].

\subsubsection{Dry Atmospheric Deposition}

Dry deposition samples $(\mathrm{n}=35)$ were collected in a polyethylene bucket (with $707 \mathrm{~cm}^{2}$ collection area) filled with $2 \mathrm{~L}$ of deionized water. Before exposing, the bucket $(30 \mathrm{~cm}$ diameter and $33 \mathrm{~cm}$ height) was cleaned with phosphorus free detergent, rinsed with deionized water and placed on $1.5 \mathrm{~m}$ height flat platform [46]. Start and end times were recorded for each sampling day in the all the stations. After the time of exposure, the water was retrieved and the final volume measured before being transferred into clean sample bottles and transported to the Centre de Recherche en Sciences Naturelles (CRSN/Lwiro) laboratory for analysis.

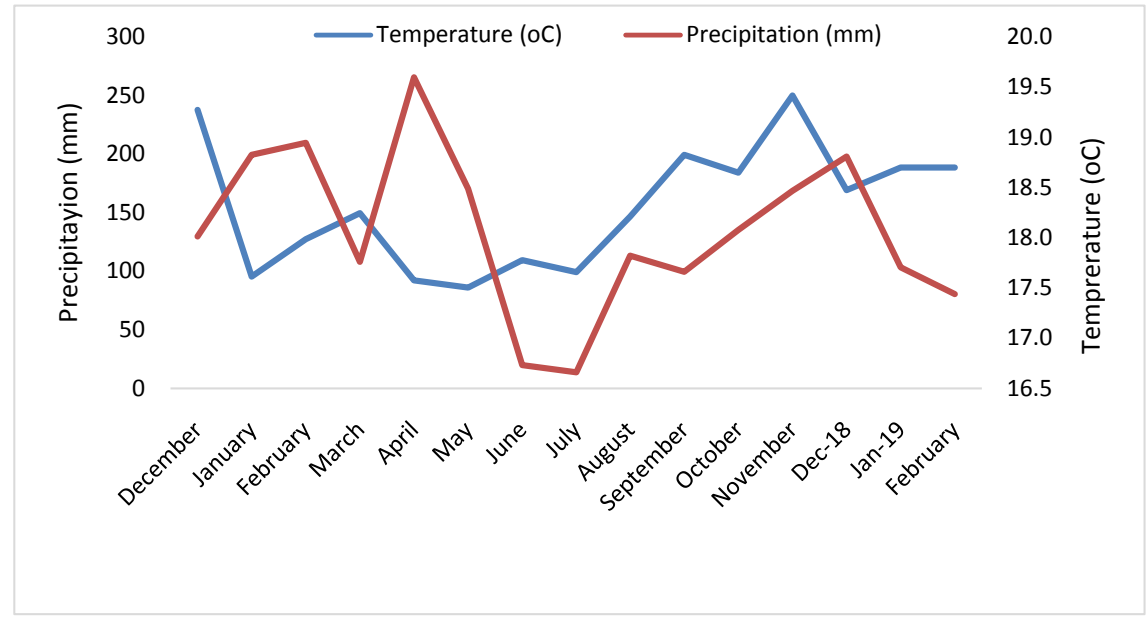

Figure 2. Monthly air temperature and precipitation at Lwiro averaged over the last 5 years (CRSN-Lwiro Meteorological station at western part of the lake). 


\subsubsection{Wet Atmospheric Deposition}

Sampling for wet atmospheric deposition $(\mathrm{n}=35)$ was done for a given rain event, three times a month. If it rained more than 3 times per month only rain events separated by 3 or more days were considered. Buckets were placed out immediately before a rain event or late in the evening if rain was expected during the night at the four stations in the different land use/cover sites in the basin. Buckets were placed on elevated stands to avoid rain splash interference. Buckets were retrieved immediately after a rain event or in the morning following overnight events and the analysis of nutrients (TP, TDP, SRP, TN, TDN, $\mathrm{NO}_{3}^{-}$and $\mathrm{NH}_{4}^{+}$) were conducted in the same way as for dry deposition.

\subsubsection{Laboratory Analysis}

Electrical conductivity (EC), $\mathrm{pH}$ and volume measurements were conducted immediately when the samples arrived at the laboratory. A sub-sample was filtered through $0.45 \mu \mathrm{m} \mathrm{GF} / \mathrm{F}$ membrane filters for particulate and dissolved analyses [47]. Phosphorus and $\mathrm{N}$ concentrations were measured following methods of APHA [48] and Wetzel and Likens [49]. Analyses of TP (unfiltered water) and total dissolved phosphorus (TDP, filtered water) were performed using potassium persulfate digestion. This was followed by the colorimetric, ascorbic ac$\mathrm{id} /$ molybdate method, to ascertain soluble reactive phosphorus (SRP). Total nitrogen (TN, unfiltered) and total dissolved nitrogen (TDN, filtered) was measured using potassium persulfate digestion followed by the colorimetric indophenol blue method. Nitrate $\left(\mathrm{NO}_{3}^{-}\right.$, colorimetric after zinc reduction) and ammonium $\left(\mathrm{NH}_{4}^{+}\right.$, colorimetric indophenol blue method) were measured immediately after sample collection. Sometimes filtered samples were stored at $4^{\circ} \mathrm{C}$ in polyethylene bottles for no more than two days prior to analysis. All these analyses were done at the laboratory of Biology of CRSN/Lwiro.

\subsubsection{Computation of Dry and Wet Atmospheric Deposition Rates}

Dry deposition rates were calculated in terms of concentration $\left(\mu \mathrm{mol} \cdot \mathrm{m}^{-2}\right.$ per day) using Equation (1):

$$
D=\frac{24 C V}{A H}
$$

where:

$$
\begin{aligned}
& D=\text { nutrient deposition }\left(\mu \mathrm{mol} \cdot \mathrm{m}^{-2} \cdot \mathrm{day}^{-1}\right) ; \\
& C=\text { nutrient concentration in sample }(\mu \mathrm{mol} / \mathrm{L}) ; \\
& V=\text { total volume of sample at end of collection period }(\mathrm{L}) A=\text { surface area of }
\end{aligned}
$$
collection bucket $\left(\mathrm{m}^{2}\right)$;

$H=$ number of hours that sample basin was deployed.

Nutrient deposition in wet was quantified in $\mu \mathrm{mol} \cdot \mathrm{m}^{-2}$ per event. After nutrient analyses, the nutrient deposition rate for rain event was calculated using the Equation (2):

$$
D=\frac{C V}{A}
$$


where:

$D=$ nutrient deposition $\left(\mu \mathrm{mol} \cdot \mathrm{m}^{-2} \cdot\right.$ event $\left.^{-1}\right)$;

$C=$ nutrient concentration in sample $\left(\mu \mathrm{mol} \cdot \mathrm{L}^{-1}\right) V=$ total volume of collected rainfall (L);

$A=$ surface area of collection bucket $\left(\mathrm{m}^{2}\right)$.

To estimate monthly wet deposition, we first calculated the volume-weighted mean (VWM) concentration of nutrients in rain samples for each month, as in Equation (3):

$$
\mathrm{VWM}=\frac{(C 1 \times V 1+C 2 \times V 2+C 3 \times V 3+\ldots)}{(V 1+V 2+V 3+\ldots)}
$$

where: $C$ is the concentration of nutrient in a given sample and $V$ is the volume of that sample.

The VWM concentration for a nutrient was multiplied by the total monthly rainfall to determine total monthly wet deposition of a given nutrient. To determine the annual dry deposition over the entire lake, the mean daily deposition rate was multiplied by the lake area $\left(2370 \mathrm{~km}^{2}\right)$ and the number of dry days per year (201), based on the long-term meteorological record in the region [22]. Following the protocol of Bootsma and Hecky [46], dry deposition was assumed to be negligible on days with rain. The total precipitation during the period of the study at the meteorological station of Lwiro/Iko was $1722 \mathrm{~mm}$ with 152 days of rain, $932 \mathrm{~mm}$ at the station of Goma, and $594 \mathrm{~mm}$ at the meteorological station of Bukavu.

\subsubsection{Statistical Analysis}

Descriptive statistical methods were used to determine the average, standard deviation, standard errors, minimum and maximum values for different time periods, stations and land uses/covers. Monthly and annual concentrations of parameters for each station were calculated by daily collected samples. Analysis of variance (ANOVA), t-test analysis and least significant difference (LSD) calculations at $\mathrm{p}=0.05$ were performed to identify statistically significant differences between land uses/covers, stations, seasons and months using the PASS software package for Windows.

\section{Results}

\subsection{Spatio-Temporal Variation of Nutrients}

Temporal variation of phosphorus (SRP, TP and TDP) in wet atmospheric deposition at the different stations around Lake Kivu basin is presented in Figure 3.

The concentration of phosphorus in the wet deposition varied over the study period and the recorded values were also different for the four stations. However, there was a similar trend for all the stations whereby two peaks were recorded; one between February and May and the other between August and November. The peaks coincided with the rainy seasons as depleted in Figure 2. In general, 


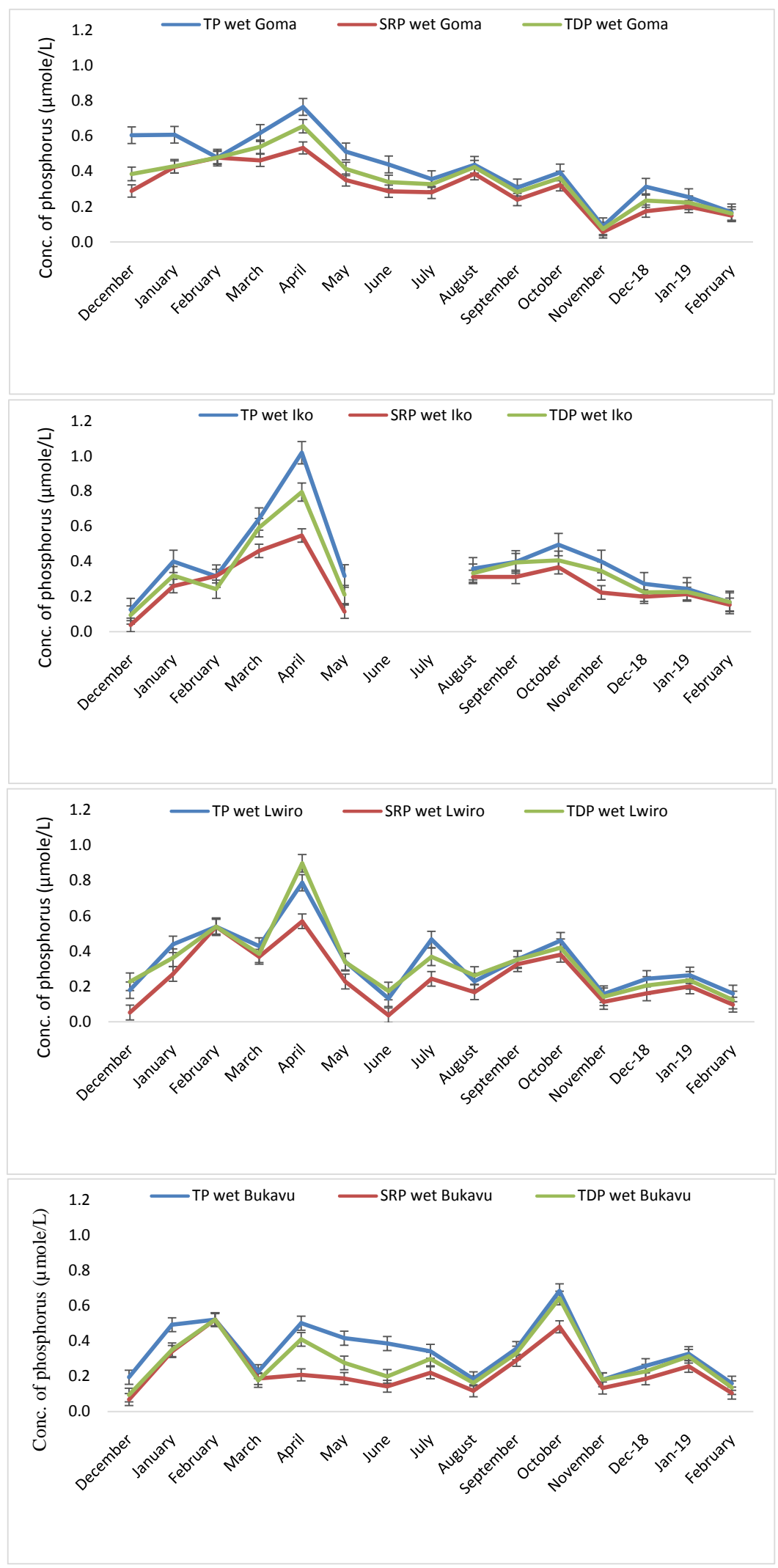

Figure 3. Temporal variation of mean phosphorus concentrations in wet atmospheric deposition at four stations around the Lake Kivu basin. Error bars represent $\mathrm{SE}$ of the mean $\mathrm{n}=3$ for each month. 
relatively high concentrations of phosphorus in the wet atmospheric deposition were recorded in April and low values were recorded in November. The maximum and the low concentration for phosphorus were recorded at Iko station.

Temporal variation of nitrogen (TN, TDN, $\mathrm{NH}_{4}^{+}, \mathrm{NO}_{3}^{-}$) in wet atmospheric deposition at the different stations around Lake Kivu basin is presented in Figure 4.

High nitrogen concentration was recorded in the period covering December-February and June-August in the three stations (Bukavu, Goma and Lwiro) except for Iko station. Concentrations of $\mathrm{NH}_{4}^{+}$and $\mathrm{NO}_{3}^{-}$were almost the same at the different stations except for Iko, where peaks were different. At Iko, only one peak was recorded in February and the trend remained the same for other months. In general, the trends of nitrogen were similar in the basin with small variation in the concentrations except for Iko were apart from the two months without precipitation (June and July because the volume collected was too small to analyze), the shape of the curve is different from that found in the other stations are shown on the next page.

\subsection{Dry Deposition Rates of Nutrients}

The temporal variation of phosphorus (SRP, TP and TDP) deposition rates at all the stations around the Lake Kivu basin is shown in Figure 5. High rates of $P$ deposition were recorded in March-May and in September-October. Highest values were recorded at Goma station in May, October in Bukavu, April in Lwiro and March in Iko. All the high deposition rates were recorded during the wet season. Similar trends were observed at Goma and Lwiro where the trend is similar with a major peak in April-May and a decrease in concentration the other months. But around October we observed another peak but in low concentration which increased until the end and the beginning of the year. On the other hand, for the curves of Iko and Bukavu, apart from the peak of April-May, we observed another peak in August for Iko and October for Bukavu.

The Dry deposition rates of $\mathrm{N}\left(\mathrm{TN}, \mathrm{TDN}, \mathrm{NH}_{4}^{+}, \mathrm{NO}_{3}^{-}\right.$) were different at the four stations (Figure 6). The highest rates were recorded at Goma (in December) and at Bukavu (in October). The lowest values were recorded at Iko in September. In Goma, high deposition rates were recorded in December, March and May before the regular trend from June to November and increased relatively in December to February. High deposition rates were recorded at Lwiro in January and after small variations in others months. A decreased concentration of deposition rate was recorded in September before it stabilized in other months with small variations. At Iko, 3 peaks were recorded, a relative high peak in March before the highest in August and a relatively high peak in November. While, in Bukavu 3 peaks were recorded with different intensity, one relatively high in March, another with moderate intensity in June and the highest in October before it normalized with small variations. In general, deposition rates of nutrients varied between months ( $p>0.001)$ in the Lake Kivu basin. 


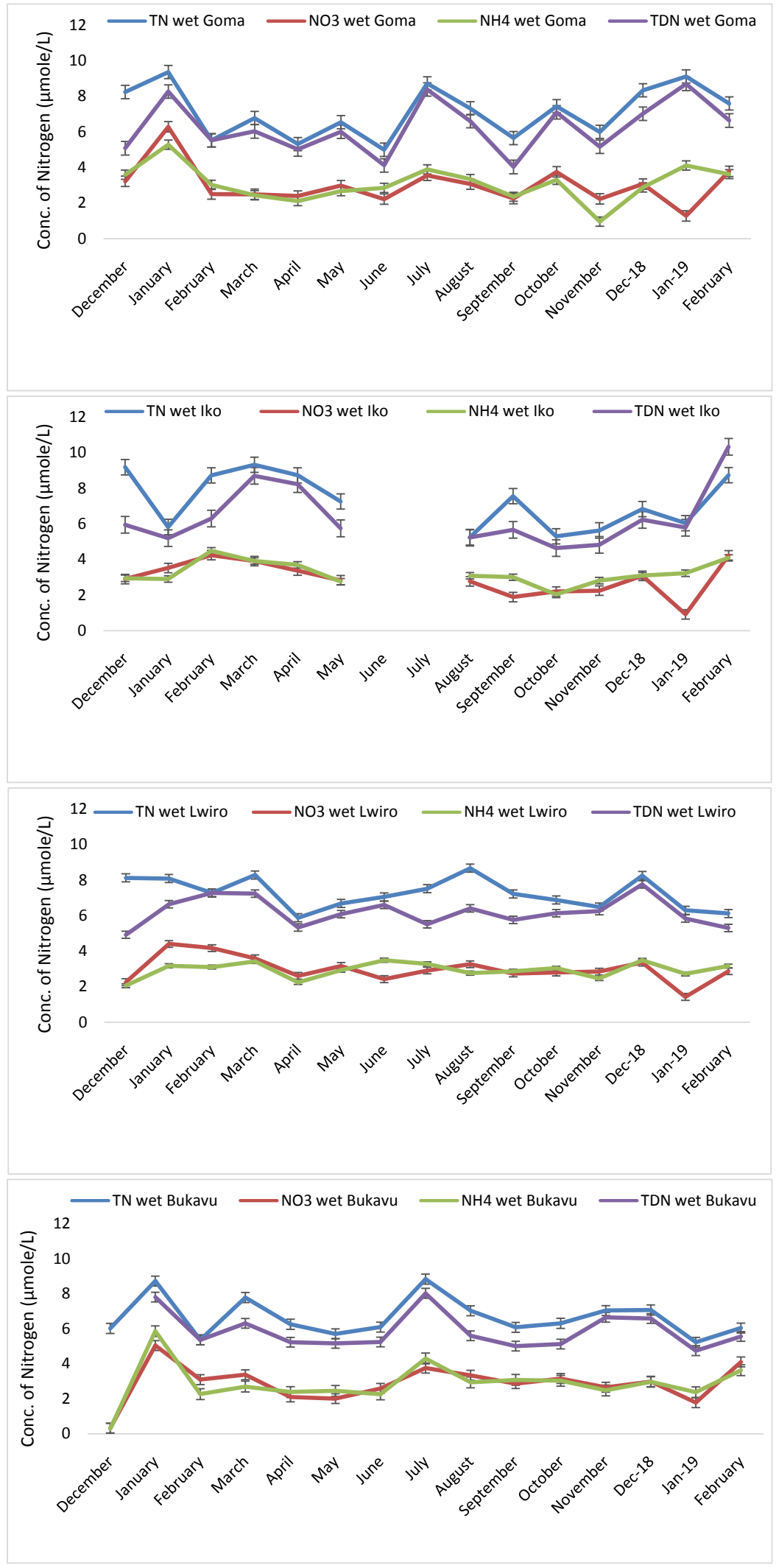

Figure 4. Temporal variation of mean nitrogen concentrations in wet atmospheric deposition at four stations around the Lake Kivu basin. Error bars represent SE of the mean $\mathrm{n}=3$ for each month. 


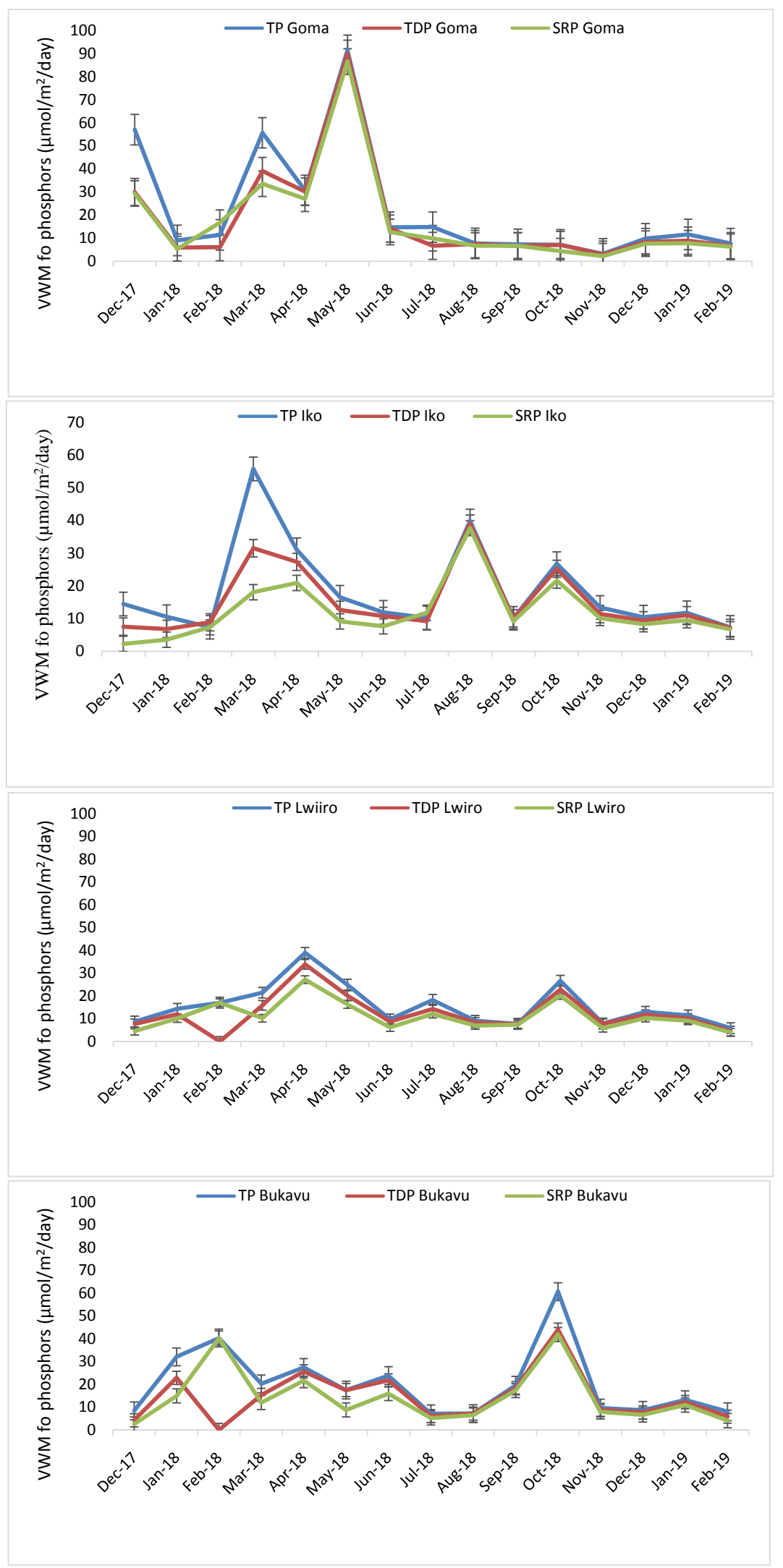

Figure 5. Temporal variation of dry $\mathrm{P}$ deposition rates $\left(\mu \mathrm{mol} / \mathrm{m}^{2} /\right.$ day) at four stations around the Lake Kivu basin. 


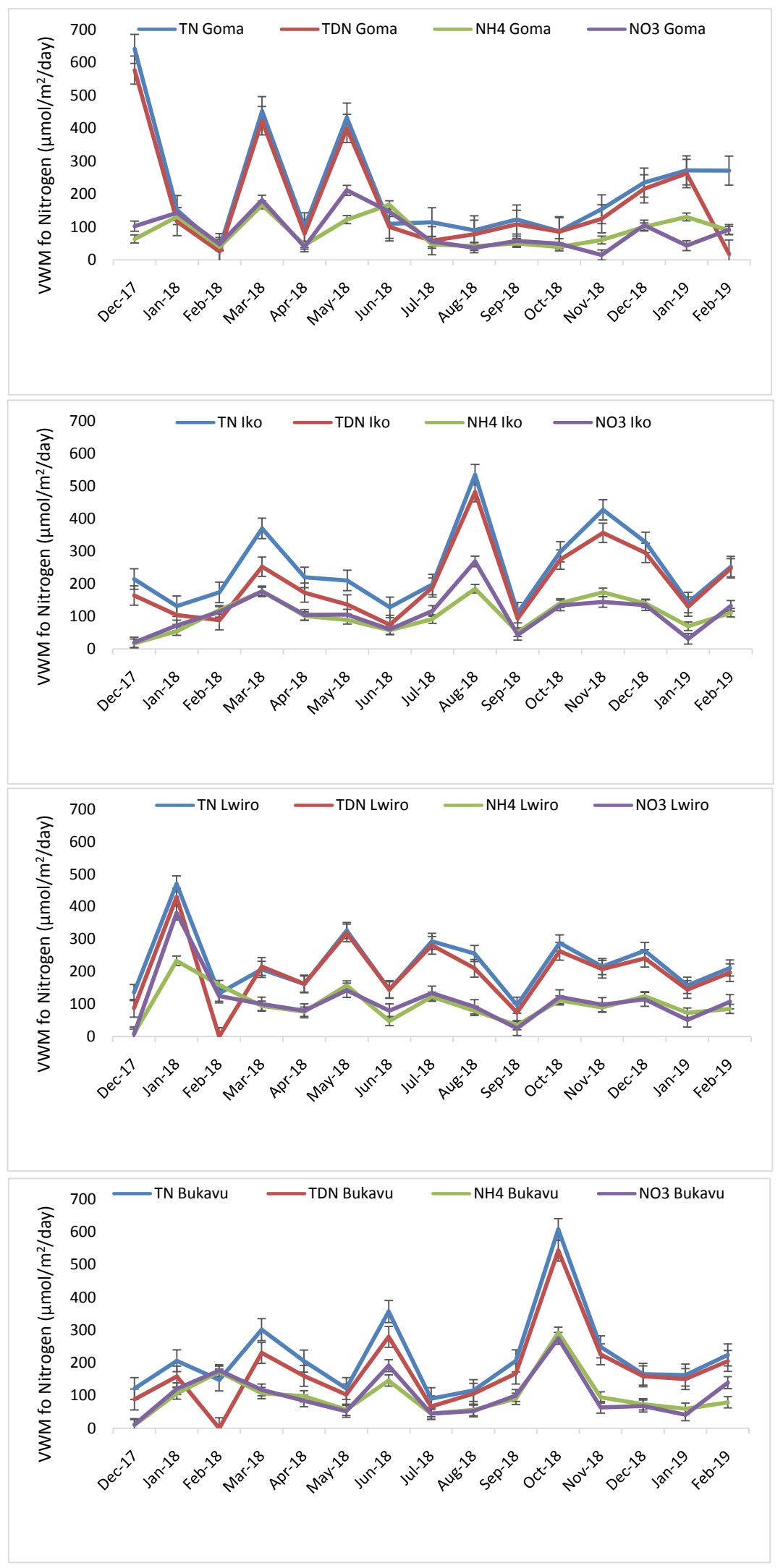

Figure 6. Temporal variation of dry $\mathrm{N}$ deposition rates $\left(\mu \mathrm{mol} / \mathrm{m}^{2} /\right.$ day) at four stations around the Lake Kivu basin. 


\subsection{Seasonal Variation of Nutrients}

In order, to investigate the relationship between precipitation and concentration of TP and TN, trends were analyzed between mean TP and TN and rainfall in the basin. It showed a similar trend with rainfall during this period of study for TP while TN remained almost at the same range with slight increased peaks in March and July as shown in Figure 7.

There results showed that there was a significant linear relationship between $\mathrm{TP}$ and precipitation $(\mathrm{t}=2.132, \mathrm{p}=0.05)$. The concentration of phosphorus followed a similar trend to that of rainfalls. There were high concentrations of phosphorus during the wet season (September to December) which dropped in the dry season (June to August). However, the annual loads were higher in the dry season as shown in Table 1.

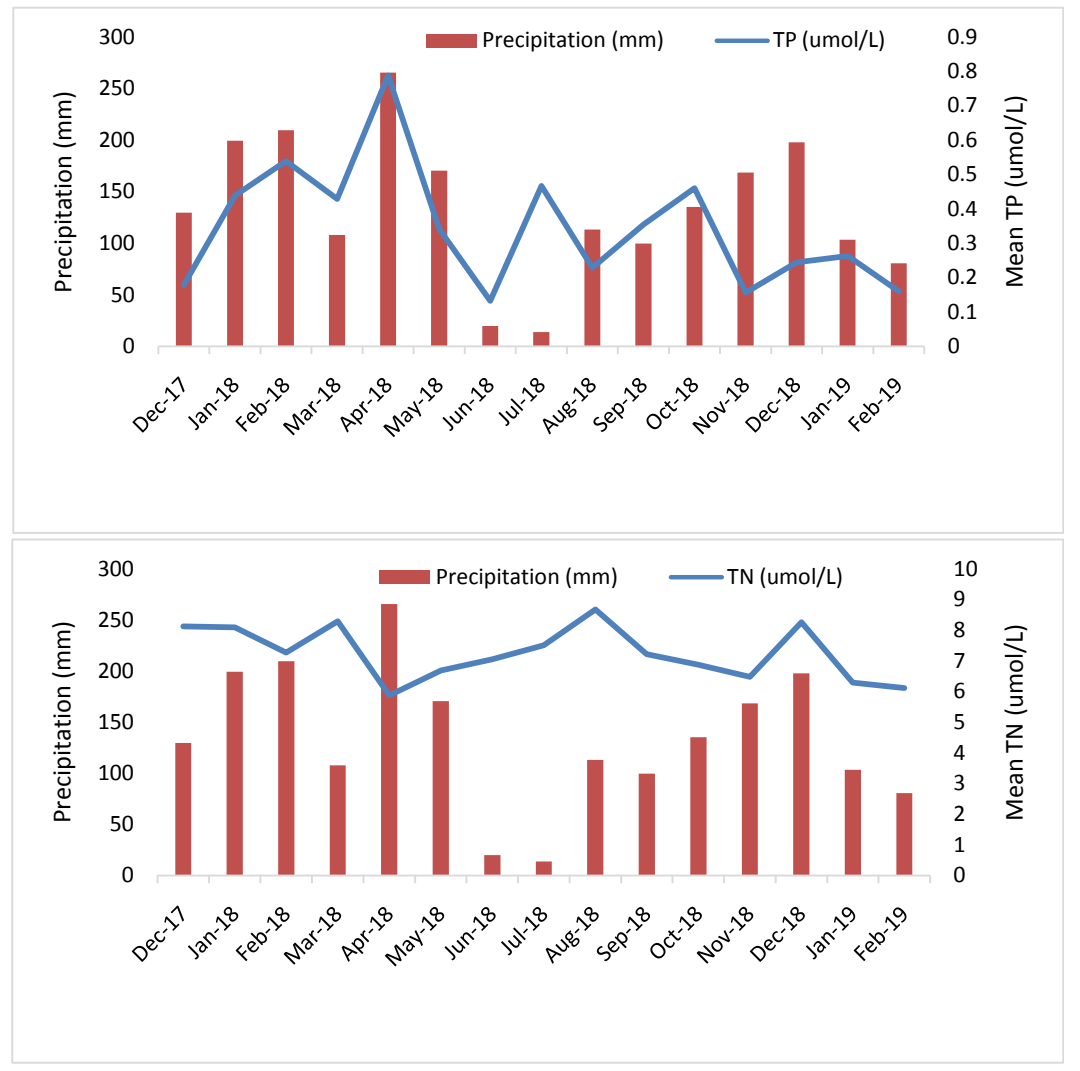

Figure 7. Mean TP and TN concentration in wet deposition in relation to precipitation.

Table 1. Annual load of TP and TN in dry and wet deposition around Lake Kivu basin $\left(\mu \mathrm{mol} / \mathrm{m}^{2} / \mathrm{yr}\right)$.

\begin{tabular}{ccccccccc}
\hline & \multicolumn{2}{c}{ Iko } & \multicolumn{2}{c}{ Lwiro } & \multicolumn{2}{c}{ Bukavu } & \multicolumn{2}{c}{ Goma } \\
\cline { 2 - 9 } & TP & TN & TP & TN & TP & TN & TP & TN \\
\hline Dry & $2.8 \pm 2.1$ & $84.5 \pm 41.2$ & $2.4 \pm 1.4$ & $75.8 \pm 32.6$ & $2.3 \pm 2.3$ & $74 \pm 43.9$ & $4.4 \pm 3.9$ & $73.7 \pm 22.3$ \\
Wet & $0.7 \pm 0.8$ & $21.7 \pm 34.7$ & $0.7 \pm 0.9$ & $21.4 \pm 33.2$ & $0.7 \pm 1.1$ & $16.7 \pm 25.1$ & $0.3 \pm 0.4$ & $10.2 \pm 16.7$ \\
\hline
\end{tabular}


The concentration of nitrogen and the loads (Table 1) were also higher during the wet season. Regression depicted no correlation between TN and precipitation $(\mathrm{t}=-0.365, \mathrm{p}=0.721)$.

In general, annual dry deposition rate of nutrients was greater than annual wet deposition in the stations around Lake Kivu basin. High dry TP annual load $\left(4.4 \pm 3.9 \mu \mathrm{mol} / \mathrm{m}^{2} / \mathrm{yr}\right)$ was recorded at Goma and the lowest at Bukavu $(2.3 \pm$ $2.3 \mu \mathrm{mol} / \mathrm{m}^{2} / \mathrm{yr}$ ). For annual dry TN load, the highest values were found at Iko $\left(84.5 \pm 41.2 \mu \mathrm{mol} / \mathrm{m}^{2} / \mathrm{yr}\right)$ and the lowest at Goma $\left(73.7 \pm 22.3 \mu \mathrm{mol} / \mathrm{m}^{2} / \mathrm{yr}\right)$. For concentration of wet TP deposition annual load, high values were record at $\mathrm{Bu}$ kavu $\left(0.7 \pm 1.1 \mu \mathrm{mol} / \mathrm{m}^{2} / \mathrm{yr}\right)$ and lowest at Goma $\left(0.3 \pm 0.4 \mu \mathrm{mol} / \mathrm{m}^{2} / \mathrm{yr}\right)$. Whereas, the highest annual wet TN load were recorded at Iko $(21.7 \pm 34.7$ $\left.\mu \mathrm{mol} / \mathrm{m}^{2} / \mathrm{yr}\right)$ and the lowest values at Goma $\left(10.2 \pm 16.7 \mu \mathrm{mol} / \mathrm{m}^{2} / \mathrm{yr}\right)$. Agriculture was the main activity in Lwiro and Iko areas.

Loading of nitrogen and phosphorus are depicted in Figure 8. Nutrient loads were higher during the dry season $(\mathrm{F}=78.75, \mathrm{p}<0.001)$. High load of TP during the dry season was recorded at Goma $\left(4.4 \pm 3.9 \mu \mathrm{mol} / \mathrm{m}^{2} / \mathrm{yr}\right)$ while the lowest were recorded at Lwiro $\left(2.95 \pm 2.6 \mu \mathrm{mol} / \mathrm{m}^{2} / \mathrm{yr}\right)$. Loading of $\mathrm{TN}$ in the basin were significantly different in dry season $(\mathrm{F}=104.9, \mathrm{p}<0.001)$. The highest loads of TN during the dry season were recorded at Lwiro $(124.8 \pm 60.8$ $\left.\mu \mathrm{mol} / \mathrm{m}^{2} / \mathrm{yr}\right)$, while the lowest were recorded at Iko $\left(84.5 \pm 41.2 \mu \mathrm{mol} / \mathrm{m}^{2} / \mathrm{yr}\right)$.

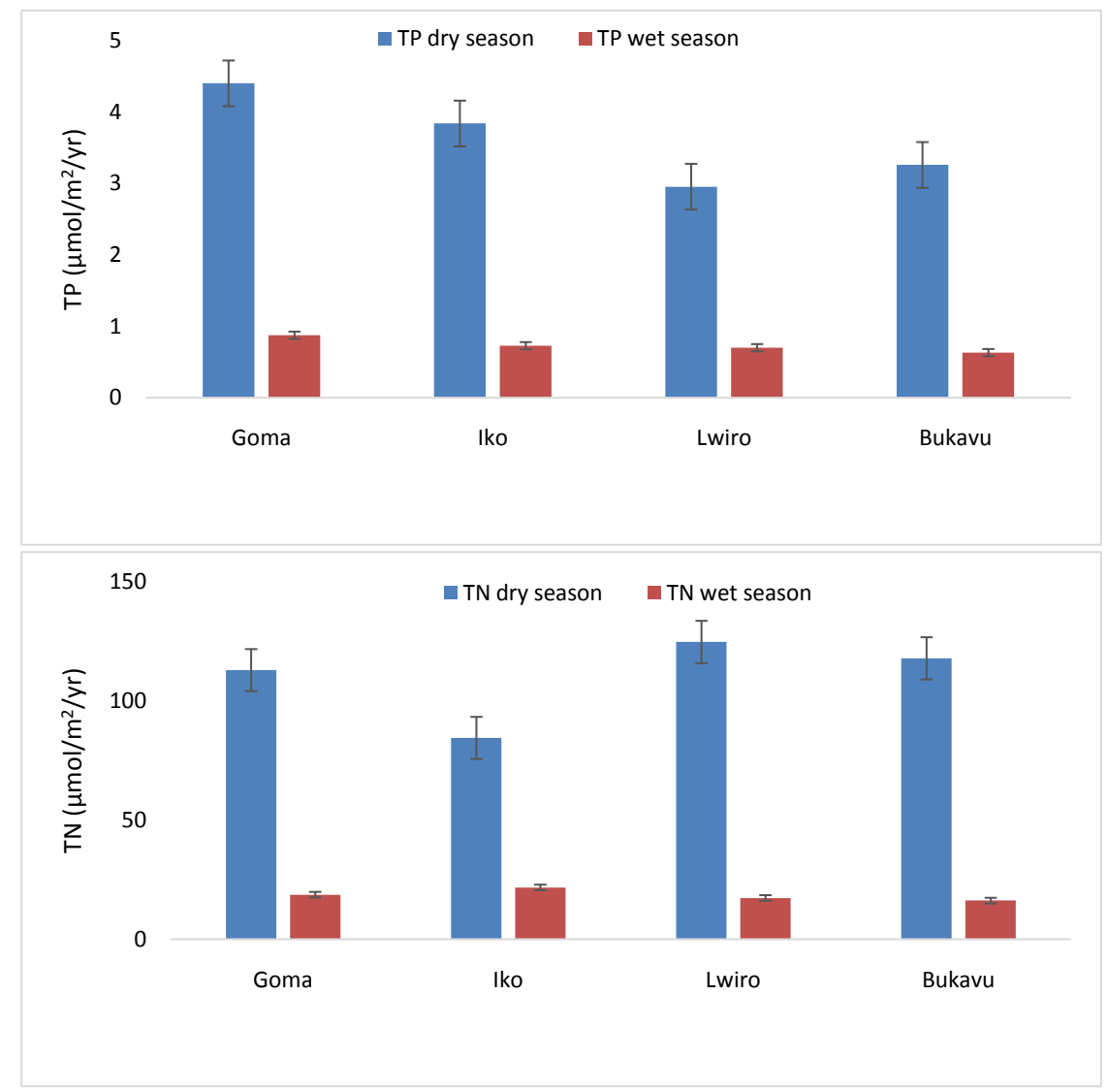

Figure 8. Variation of TP and TN loads in atmospheric deposition at different locations. 


\subsection{Land Use/Cover and Atmospheric Nutrient Deposition}

There were differences between land use types in both dry and wet deposition. Volume-weighted mean (VWM) concentrations of dry TP and TN in the 4 stations around the Lake Kivu basin versus land use/cover are presented in Figure 9.

The highest dry TP VWM loading was recorded in the forest followed by the agricultural area. The lowest loading was recorded in built-up area. The VWM highest loading of dry deposition of TP was record at Goma in the forest area while the lowest was recorded at Goma in the built-up area. For VWM of dry $\mathrm{TN}$, the loading was also high in the forest area. The highest values were recorded at Lwiro (forest area) and the lowest in the wetland area at Goma. The V W M of wet TP and TN in the four stations around the Lake Kivu basin vs land use/cover are presented in Figure 10.

VWM loading of wet TP and TN are presented in the Figure 10. The highest wet TP VWM loading was record in the forest followed by agricultural for TP deposition. The lowest loadings were recorded in both wetland and built-up areas. The VWM loading of wet TP deposition was recorded at Goma in the agricultural area while the lowest in the wetland area at Lwiro. For VWM of wet $\mathrm{TN}$, the loading was also high in the agricultural area. The highest values were recorded at Iko and the lowest in the wetland at Bukavu. However, no statistically difference was recorded at the four stations $(\mathrm{F}=0.876, \mathrm{p}=0.485)$.

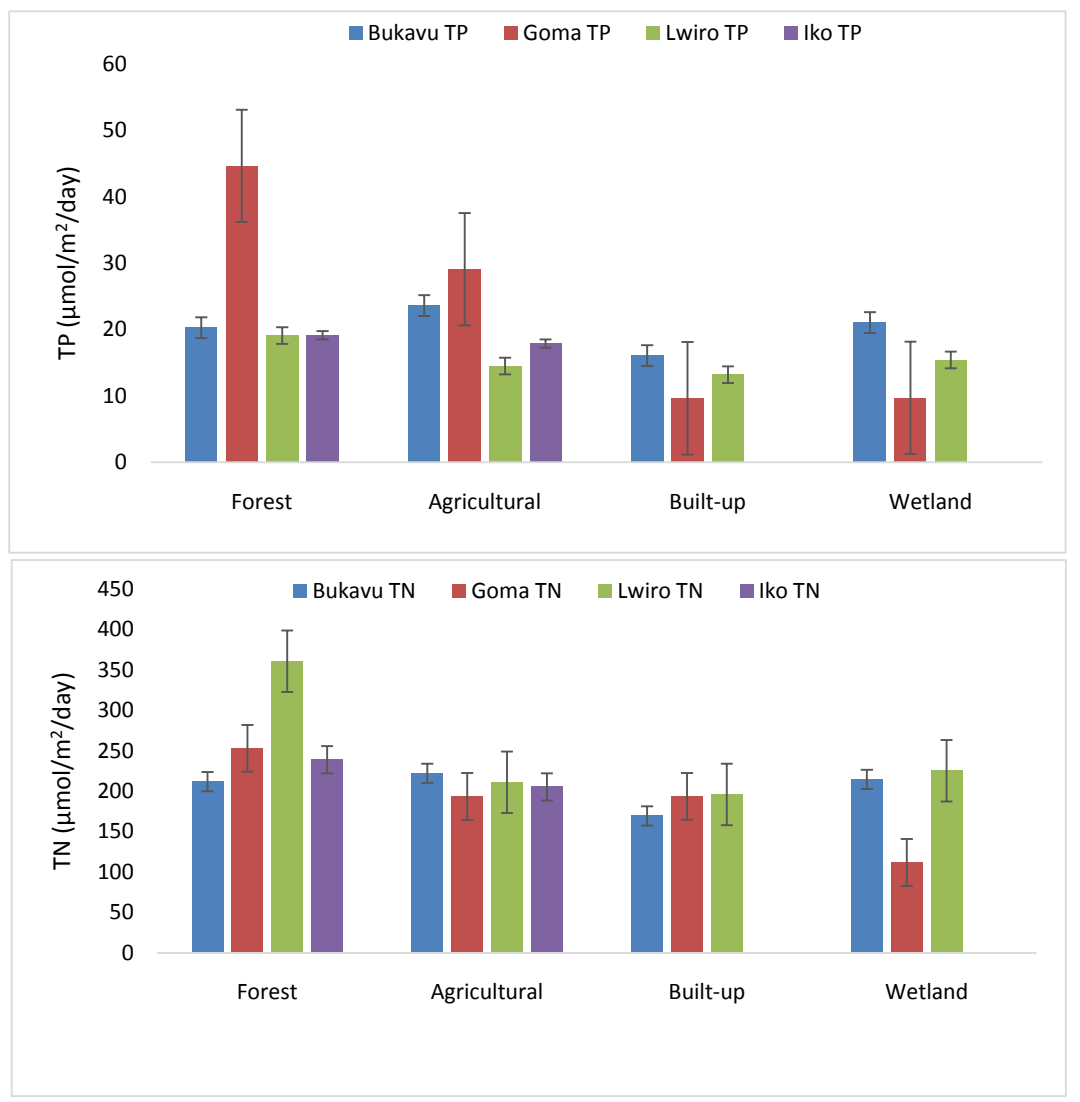

Figure 9. Mean daily dry TP and TN deposition at four stations around Lake Kivu $(\mathrm{n}=35)$. 


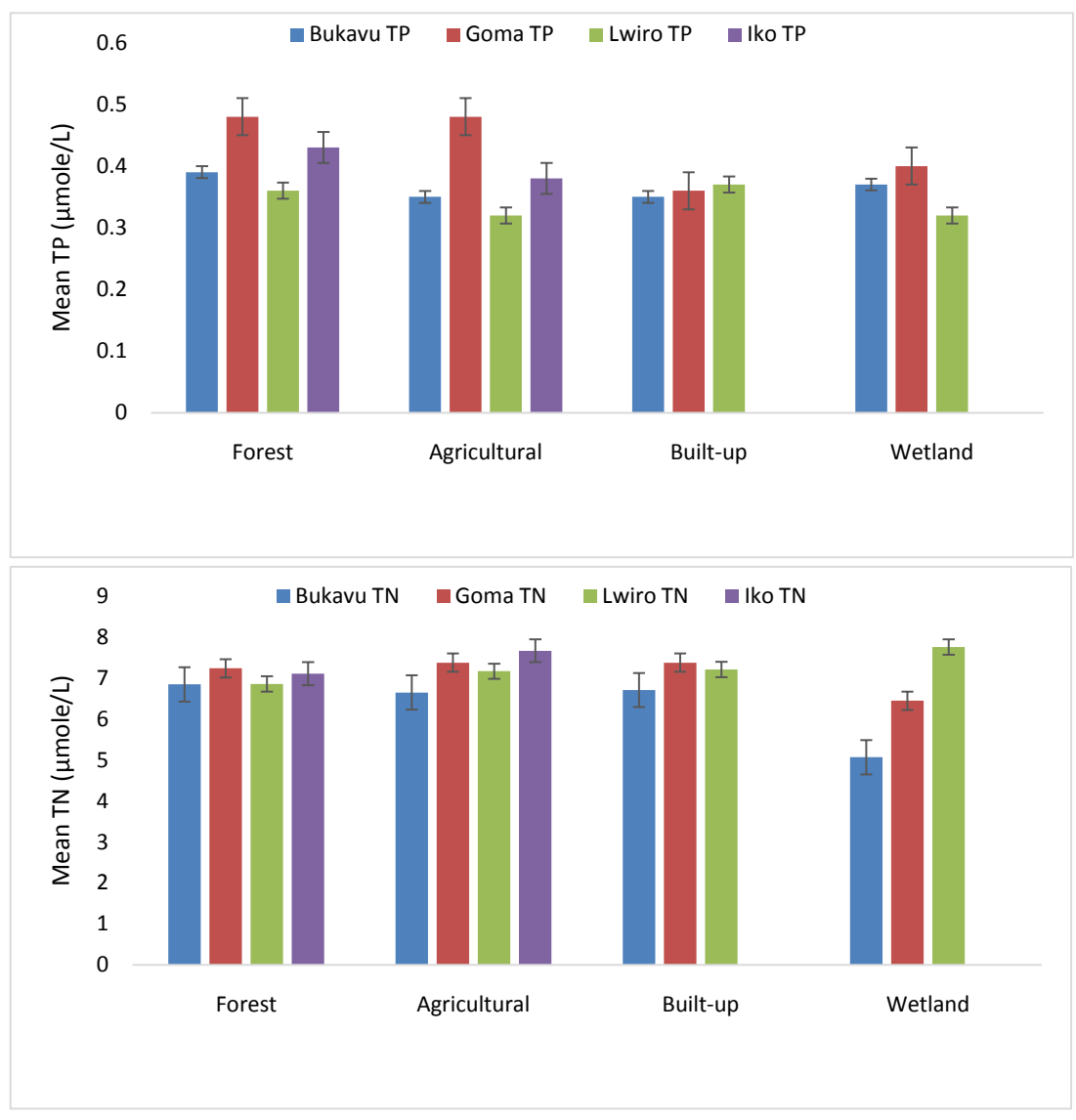

Figure 10. Mean TP and TN concentrations $(\mu \mathrm{mol} / \mathrm{L})$ recorded in wet deposition in four stations around Lake Kivu basin $(\mathrm{n}=35)$.

VWM recorded in each station versus land use/cover revealed differences in wet deposition of TP and TN. There are significant differences $(\mathrm{p}<0.001)$ between land use/cover and wet TP and TN deposition in the different stations taken alone.

\subsection{Sources of Nutrients}

There was a variation of TP and TN loading in atmospheric deposition during the different agricultural activities (from clearing to harvesting) at Iko and Lwiro stations. Figure 11 presents the variation of TP and TN during agricultural process in the agricultural area of Iko and Lwiro.

In general, the concentration of nutrients (TP and $\mathrm{TN}$ ) was highest during the period of clearing land and planting in the first agricultural season. In the second season, high concentrations were recorded during the clearing of land and harvesting period followed by planting period. During the planting period, the concentration of TP increased compared to clearing time in the first agriculture season (September to December) but in the second agricultural season (February to May) similar trends were observed but with less concentration. Whereas, in the first agricultural season, TN concentrations were high during the clearing and planting period, this decreased in the harvesting period. However, in the second 
agricultural period, TN concentrations were high in clearing and harvesting time. Table 2 provides a comparison of the mean TP and TN in agricultural and urban areas.

High concentrations of TP were recorded in wet and dry seasons in agricultural area than urban area. TP showed no significant difference between the season and areas. However, variation of TN concentrations was quite high in wet season in the agricultural area and high in dry season in the urban area. There was also no significant difference between TN concentrations in agricultural and urban areas $(\mathrm{p}>0.05)$. Generally, area where agricultural is the main activity (Lwiro and Iko stations), relatively high TP concentrations were record in both dry and wet seasons while relatively high TN were observed in both wet season in agricultural area and in dry season in urban area.

Pearson correlation was used to determine the source of nutrients in the basin as shown in Table 3. Nutrients were found to be correlated with their natural sources in the atmosphere.

The Pearson correlation indicates that some nutrients are strongly correlated such as TP with TDP (TP-TDP), TP-SRP, SRP-TDP, TN-TDN and $\mathrm{NO}_{3}^{-}-\mathrm{NH}_{4}^{+}$ in wet deposition; while TN-SRP and TDN-SRP were significantly correlated. High correlation between all $\mathrm{P}$ forms revealed that the source of the nutrient is dissolved but also particulate. TN is strongly correlated with TDN but not with $\mathrm{NH}_{4}^{+}$and $\mathrm{NO}_{3}^{-}$. In general, nutrient was weakly correlated in wet atmospheric deposition.

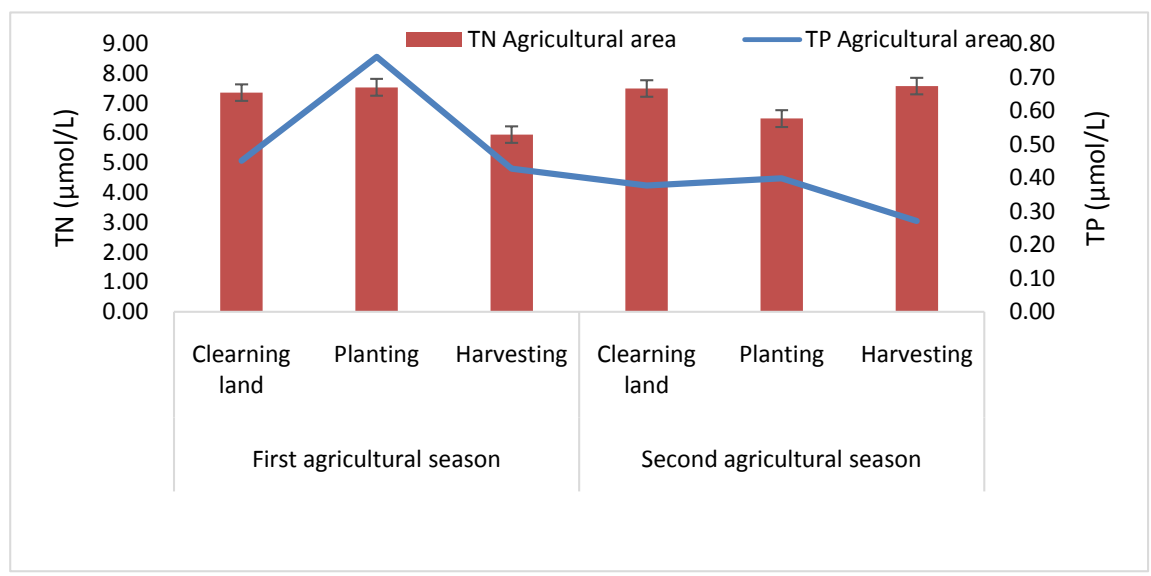

Figure 11. Variation of TP and TN concentration in wet deposition during agricultural process in Lwiro and Iko stations.

Table 2. Mean TP and TN ( $\mu \mathrm{mol} / \mathrm{L})$ in wet atmospheric deposition around Lake Kivu.

\begin{tabular}{ccccc}
\hline & \multicolumn{2}{c}{ Wet season } & \multicolumn{2}{c}{ Dry season } \\
\cline { 2 - 5 } & $\mathrm{TP}(\mu \mathrm{mol} / \mathrm{L})$ & $\mathrm{TN}(\mu \mathrm{mol} / \mathrm{L})$ & $\mathrm{TP}(\mu \mathrm{mol} / \mathrm{L})$ & $\mathrm{TN}(\mu \mathrm{mol} / \mathrm{L})$ \\
\hline Agricultural area & $0.41 \pm 0.17$ & $7.3 \pm 0.39$ & $0.4 \pm 0.04$ & $6.67 \pm 1.89$ \\
Urban area & $0.36 \pm 0.09$ & $6.8 \pm 0.3$ & $0.29 \pm 0.1$ & $7.53 \pm 0.85$ \\
\hline
\end{tabular}


Table 3. Pearson correlation of mean nutrients species in wet deposition.

\begin{tabular}{cccccccc}
\hline & TP & TDP & SRP & TN & TDN & $\mathrm{NH}_{4}^{+}$ & $\mathrm{NO}_{3}^{-}$ \\
\hline $\mathrm{TP}$ & 1 & & & & & & \\
$\mathrm{TDP}$ & $0.92^{* * *}$ & 1 & & & & & \\
$\mathrm{SRP}$ & $0.87^{* * *}$ & $0.87^{* * *}$ & 1 & & & & \\
$\mathrm{TN}$ & 0.45 & 0.41 & $0.13^{*}$ & 1 & & & \\
$\mathrm{TDN}$ & 0.42 & 0.45 & 0.13 & $0.96^{* * *}$ & 1 & & \\
$\mathrm{NH}_{4}^{+}$ & 0.30 & 0.25 & 0.31 & 0.34 & 0.31 & 1 & \\
$\mathrm{NO}_{3}^{-}$ & 0.31 & 0.27 & 0.27 & 0.39 & 0.30 & $0.85^{* * *}$ & 1 \\
\hline
\end{tabular}

Legend: ${ }^{*}=$ significant correlated and ${ }^{* *}=$ strong significant correlated.

TN, TDN, $\mathrm{NH}_{4}^{+}$and $\mathrm{NO}_{3}^{-}$are not correlated with $\mathrm{P}$ all forms except the correlation of TN and SRP. $\mathrm{NH}_{4}$ is not correlated with others nutrients forms in wet deposition. While $\mathrm{NO}_{3}^{-}$is strong correlated only with $\mathrm{NH}_{4}^{+}$.

Pearson correlations in dry atmospheric deposition of nutrients around Lake Kivu are present in Table 4.

In dry deposition, strong correlation was observed in many species of nutrients. TP was strongly correlated with TDP, SRP and TDP-SRP as in wet atmospheric deposition showing that the P loading was in dissolved form. TN was weakly correlated with $\mathrm{TDN}, \mathrm{NH}_{4}^{+}$and $\mathrm{NO}_{3}^{-}$. Nitrogen all forms are not correlated with phosphorus all forms. The correlation is only recorded in the each form of nutrients.

\section{Discussion}

\subsection{Spatio-Temporal Variation of Nutrients}

Spatio-temporal variation of nutrients varied in the stations around Lake Kivu basin. High nutrient loads were recorded in forest and agricultural areas than in others land use/cover in the basin. High nutrient loadings in the forest area are probably due to the retention of dust containing nutrients when the wind blow through the forest released. These nutrients are then released in the in the surrounding area through wet or dry deposition. Land used/cover located at Goma had high values of nutrient loadings in the basin. Agricultural area was a second contributor of nutrient to the Lake Kivu basin. This was observed in the study which depended on the anthropogenic activities in the basin like biomass burning practice in agriculture, cement industry, transport in mud road common in built-up area, fishponds in wetland and reforestation and a forestation in forested areas. About the factors responsible of the variation of nutrients atmospheric deposition, wind was a very important factor for transportation and dispersion of atmospheric nutrients [50]. The trend of TP and rainfall could explain the observed concentrations of phosphorus in the dry season and concentration of nitrogen in wet the season. This observation is in line with a similar study by Vuai et al. [51] in Lake Victoria basin where it was found that spatial variation of 
Table 4. Person correlation of mean nutrients species in dry deposition.

\begin{tabular}{cccccccc}
\hline & TP & TDP & SRP & TN & TDN & $\mathrm{NH}_{4}^{+}$ & $\mathrm{NO}_{3}^{-}$ \\
\hline TP & 1 & & & & & & \\
TDP & $0.97^{* * *}$ & 1 & & & & & \\
SRP & $0.87^{* * *}$ & $0.93^{* * *}$ & 1 & & & & \\
$\mathrm{TN}$ & -0.01 & -0.09 & -0.05 & 1 & & & \\
$\mathrm{TDN}$ & 0.02 & -0.01 & 0.09 & $0.70^{* *}$ & 1 & & \\
$\mathrm{NH}_{4}^{+}$ & 0.06 & 0.03 & 0.19 & $0.53^{*}$ & $0.76^{* *}$ & 1 & \\
$\mathrm{NO}_{3}^{-}$ & 0.20 & 0.15 & 0.28 & $0.5^{*}$ & $0.61^{* *}$ & $0.74^{* *}$ & 1 \\
\hline
\end{tabular}

nutrients reflects land use activities. Zhang et al. [31] reported low concentration of chemical species in rainwater during heavy precipitation. This was also observed in the study stations in Lake Kivu basin where low concentrations of phosphorus were observed during the rainy period probably due to the dilution effect of the rain. It was found that the beginning of rain after dry season high relative concentration of nutrients is recorded in almost all the stations (April and September). The high concentration of nitrogen during the short rain might be attributed to accumulation of nutrients in the atmosphere between the two periods of sampling. This could explain why deposition rates were relatively constant over time. Langenberg et al. [21] reported the same trend in Lake Tanganyika where they found that the dissolved inorganic nitrogen (DIN) was the highest at the beginning of the rain season.

Annual wet deposition calculated as mean daily wet deposition in the four stations showed that dry deposition of nutrients (TP and TN) was greater than wet deposition on an annual basis. The finding agrees with that of Bootsma et al. [5] in Lake Malawi. Dry atmospheric deposition contributes relatively high rate of deposition of nutrients than wet deposition in the Lake Kivu basin.

\subsection{Land Use/Cover and Atmospheric Nutrient Deposition}

The results suggested that land use/cover types have different capacities of deposition of nutrients in different areas. Forested areas had high concentrations values than others land use/cover types (agricultural, wetland and built-up area). These results are different from those found by Vuai et al. [51] in Lake Victoria basin where urban and peri-urban areas showed high concentrations of nutrients ( 15.5 and $13.9 \mathrm{Kg} / \mathrm{ha} / \mathrm{yr}$ for TN and 6.1 and $2.8 \mathrm{Kg} / \mathrm{ha} / \mathrm{yr}$ for TP). Luo et al. [4] also found higher concentrations of nitrogen in atmospheric deposition in urban than in rural areas (38.9\% higher than that over the rural sites) of the State of Connecticut in USA. However, this study showed that stations located at agricultural areas have high concentration of TN in dry and wet seasons than in urban areas $(6.7-7.3 \mu \mathrm{mol} / \mathrm{L}$ respectively) and the same concentration of TP $(0.4 \mu \mathrm{mol} / \mathrm{L})$ in the two seasons.

TP volume-weighted mean concentration in rain recorded in our study was 
$0.41 \mu \mathrm{mol} / \mathrm{L}$, which is comparable to that for rain near Lake Malawi reported by Bootsma et al. [52]. Trend of deposition rates of TP in wet atmospheric deposition in the stations were range as followed deposition rates in the stations of TP for wet atmospheric deposition trend were range as followed Goma > Bukavu > Iko > Lwiro. But, this trend change for TN and became Iko > Lwiro > Bukavu > Goma, where agricultural areas came before urban areas. A similar TN trend was also observed by Vuai et al. [51] in the Lake Victoria basin where high concentration of TN from agricultural sectors (biomass burning, blowing soil from cultivated area) and aerosol emanating from mud roads in this region. The same authors reported that for Lake Victoria basin, vehicle emissions due to burning of fossil fuel were dominant. Lwiro and Iko are rural areas, characterized by agricultural land with high concentrations of phosphorus in soil [45] and high animal keeping by free range grazing which may contribute to increased atmospheric nutrients in the wet deposition. Mahowald et al. [53] reported that atmospheric phosphorus exists almost entirely in the form of aerosols due to the low volatility of phosphorus compounds. This study showed, soil blowing and ash from volcanoes and biomass burning which are common in the area are supposedly the main sources of atmospheric deposition. This was also confirmed by Graham and Duce [54] [55], who documented dominance of mineral aerosols in delivering atmospheric phosphorus to oceans and other ecosystems.

\subsection{Sources of Nutrients}

Agricultural land use/cover was the second contributor of nutrient loading to atmospheric deposition of nutrients. The stations located in rural areas (Iko and Lwiro) tended to have relatively high TN concentrations than the stations in urban areas (Bukavu and Goma). Land preparation for cultivation is actively pursued in the dry season and biomass burning follows. TP increased during the planting period compared to land clearing and harvesting time. Kollher et al. [56] concluded that land clearing and burning activities significantly increased the main nutrient input of $\mathrm{N}$ and $\mathrm{P}$ in the atmosphere. TP in urban areas especially at Goma station around active volcanoes of Virunga often released aerosols in the air that were laden with nutrients. These aerosols produced contained nutrients and other chemical particles [57]. But also, the blowing up of soil by wind during this period is responsible for increasing atmospheric nutrient deposition. Soil dust and particulate matters from cultivated and mud road in these areas are washed out at the beginning of the wet season, as also observed by Andreae [58]. This proved that aerosol from volcanoes and soil blowing is among the major contributors of nutrients in atmosphere in the Lake Kivu basin. This study also showed that agriculture and related activities have impacted atmospheric deposition rate in the basin. Biomass burning starts before planting that is probably the reason why TP increased in wet deposition during this period. The second agricultural season is very short and agricultural activities reduce during this time. But TN is higher in the period of land clearing due to the decomposi- 
tion of the biomass cutting for agricultural preparation. Lwiro and Iko are located in rural areas where agriculture is the main activity and biomass burning is intensively carried out resulting in accumulation of atmospheric particles containing nutrients. This confirms the high input of nutrients into the Lake Kivu from agricultural areas as also found in Lake Vitoria basin by Vuai et al. [51].

Phosphorus (TP, TDP and SRP) correlated, indicating that these components have a common source which may be natural or from anthropogenic activities. Aerosols in the atmosphere are an important source of phosphorus that can result from burning of biomass and blowing of soil from mud roads and agricultural. The high concentration of $\mathrm{P}$ during the period of high activities (planting and early dry season) confirmed this hypothesis of the source of $\mathrm{P}$ as also found by Bootsma and Hecky [50]. But the association of soluble and particulate $\mathrm{P}$ found in Lake Malawi basin was reported to have been deposited in the form of soluble aerosols. Correlation of nitrogen species was significant between $\mathrm{NO}_{3}^{-}$ and $\mathrm{NH}_{4}^{+}$in dry and wet atmospheric depositions. This is line with Bootsma et al. [5] observations that nitrogen was not related to particulate form. The nutrient source released compound in the atmosphere and there are dissolved in rain before to fall as dissolved form. The high correlation between any $\mathrm{NO}_{3}^{-}$ and $\mathrm{NH}_{4}^{+}$and the no correlation between TDN and $\mathrm{NH}_{4}^{+}$in wet atmospheric deposition showed that the source is not from dissolved source as gases but as aerosols. While the correlation between $\mathrm{NO}_{3}^{-}-\mathrm{NH}_{4}^{+}$and TDN revealed that nitrogen in dry atmospheric deposition take source from aerosol or biomass burning source in dissolved or particulate forms. An earlier study by Behera et al. [59] showed that the largest source of nitrogen emissions in Asia was agriculture, including animal husbandry and nitrogen-based fertilizer applications. Other sources of nitrogen included industrial processes, vehicle emissions and volatilization from soils and lakes [32]. In the Lake Kivu basin, Cuoco et al. [60] and Zirirane et al. [61] [62] reported that natural contributors of nitrogen were volcano emissions of aerosols and volatilization from wetland and Lake Kivu. Various scholars [9] [24] [53] [63] point out that the main anthropogenic contributors are agricultural activities due to biomass burning and vehicles emissions due to burning of fossil fuels within the lake basin and far from the basin. The basin has a low level of industrialization, which explains the low contributions of industries.

The correlations which were found in the samples in the basin about $\mathrm{P}$ and $\mathrm{N}$ forms were expected, because, much of the TP was TDP and TN was in form of $\mathrm{NH}_{4}$ and $\mathrm{NO}_{3}$. Vuai et al. [51] used only wet deposition and found similar correlations as observed in Lake Kivu basin. In their conclusion, the strong correlation indicated common sources of the nutrients or similar scavenging mechanism involved. The correlation may also be due to emission and dissolution of residues as a result of biomass burning, a common practice in agriculture in the region; but also aerosol mass coming from blowing soil from cultivated areas and mud roads. This was also reported by other scholars [5] [64]. 
This correlation indicated that the processes that regulated atmospheric $\mathrm{P}$ loading and deposition were different from those that affected atmospheric $\mathrm{N}$ loading and deposition. This was probably due to agricultural activities in the dry period and the blowing of soil also in the same period. As Zhang et al. [31] indicated volatilization of ammonia from agricultural activities could explain the correlation. Volatilization is done in dry period, increasing also the concentration of ammonia in the atmosphere in Lake Kivu basin.

\section{Conclusions}

This study determined atmospheric nutrient deposition under different land uses, temporal and spatial variation in four stations around Lake Kivu basin in the DR Congo side. The results revealed that there were no significant differences between deposition rates among the four types of land use (Agriculture, wetland, built-up area and forest) but also no significant difference in temporal and spatial variation. Temporal variation of nutrients in the study area showed that high concentrations of the major nutrients were observed in the wet season during planting period for cultivation but for the second season, the difference is not clear because of little agricultural activities. Agricultural areas of the basin contributed largely to atmospheric nutrient compared to towns in the DR Congo side of Lake Kivu. Lwiro and Iko areas had high agricultural activities and there was a need for smart agricultural practices in order to reduce nutrient loading, which had contributed to the eutrophication of Lake Kivu.

Correlations between nutrients species suggested that processes that regulated atmospheric $\mathrm{P}$ loading and deposition were likely to be different from the processes that affect atmospheric $\mathrm{N}$ loading and deposition in all the stations.

Further studies focusing on long-term measurements are necessary and can contribute to answer open questions on nutrient cycle changes in Lake Kivu ecosystems and to explore more about non-significant difference in temporal and spatial variation of the atmospheric depositions. While wet and dry $\mathrm{N}$ deposition measurements are available for some locations within Lake Kivu basin in DR Congo side, modeling is needed to estimate $\mathrm{N}$ and $\mathrm{P}$ deposition at locations where measurements are not possible due to lack of access.

\section{Acknowledgements}

The authors thank RUFORUM for the financial support and gratefully acknowledge the CRSN laboratory for assistance support during sample collection.

\section{Conflicts of Interest}

The authors declare no conflicts of interest regarding the publication of this paper.

\section{References}

[1] Williams, M.W. and Tonnessen, K.A. (2000) Critical Loads for Inorganic Nitrogen 
Deposition in the Colorado Front Range, USA. Ecology Application, 10, 1648-1665. https://doi.org/10.1890/1051-0761(2000)010[1648:CLFIND]2.0.CO;2

[2] Baron, J.S., Schmidt, T.M. and Hartman, M.D. (2009) Climate Induced Changes in High Elevation Stream Nitrate Dynamics. Global Change Biology, 15, 1777-1789. https://doi.org/10.1111/j.1365-2486.2009.01847.x

[3] Elser, J.J., Andersen, T., Baron, J.S., Bergstrom, A., Jansson, M., Kyle, M., Nydick, K.R., Steger, L. and Hessen, D.O. (2009) Shifts in Lake N:P Stoichiometry and Nutrient Limitation Driven by Atmospheric Nitrogen Deposition. Science, 326, 835-837. https://doi.org/10.1126/science.1176199

[4] Luo, Y., Yang, X., Carley, R.J. and Perkins, C. (2003) Effects of Geographical Location and Land Use on Atmospheric Deposition of Nitrogen in the State of Connecticut. Environmental Pollution, 124, 437-448. https://doi.org/10.1016/S0269-7491(03)00043-5

[5] Bootsma, H.A., Bootsma, M.J. and Hecky, R.E. (1996) The Chemical Composition of Precipitation and Its Significance to the Nutrient Budget of Lake Malawi. In: Johnson, T.C. and Odada, E.O., Eds., The Limnology, Climatology and Paleoclimatology of East African Lakes, Routledge, London, 251-265.

https://doi.org/10.1201/9780203748978-14

[6] Tamatamah, R., Hecky, R. and Duthie, H. (2005) The Atmospheric Deposition of Phosphorus in Lake Victoria (East Africa). Biogeochemistry, 73, 325-344. https://doi.org/10.1007/s10533-004-0196-9

[7] Larney, F.J., Bullock, M.S., Janzen, H.H., Ellert, B.H. and Olson, E.C.S. (1998) Wind Erosion Effects on Nutrient Redistribution and Soil Productivity. Journal of Soil Water Conservation, 53, 133-140.

[8] Shaw, R.D., Trimbee, A.M., Minty, H., Fricker, H. and Prepas, E.E. (1989) Atmospheric Deposition of Phosphorus and Nitrogen in Central Alberta with Emphasis on Narrow Lake. Water Air Soil Pollution, 43, 119-134. https://doi.org/10.1007/BF00175588

[9] Kocak, M., Kubilay, N. and Mihalopoulos, N. (2004) Ionic Composition of Lower Tropospheric Aerosols at a Northeastern Mediterranean Site: Implications Regarding Sources and Long-Range Transport. Atmospheric Environment, 38, 2067-2077. https://doi.org/10.1016/j.atmosenv.2004.01.030

[10] Wu, S., Mickley, L.J., Kaplan, J.O. and Jacob, D.J. (2012) Impacts of Changes in Land Use and Land Cover on Atmospheric Chemistry and Air Quality over the 21st Century. Atmospheric Chemistry and Physics, 12, 1597-1609. https://doi.org/10.5194/acp-12-1597-2012

[11] Delkash, M., Al-Faraj, F.A.M. and Scholz, M. (2018) Impacts of Anthropogenic Land Use Changes on Nutrient Concentrations in Surface Waterbodies: A Review. CLEAN-Soil, Air, Water, 46, Article ID: 1800051. https://doi.org/10.1002/clen.201800051

[12] Pearson, J. and Stewart, G.R. (1993) The Deposition of Atmospheric Ammonia and Its Effects on Plants. New Phytology, 125, 283-305. https://doi.org/10.1111/j.1469-8137.1993.tb03882.x

[13] McDowell, R.W. and Sharpley, A.N. (2009) Atmospheric Deposition Contributes Little Nutrient and Sediment to Stream Flow from an Agricultural Basin. Agriculture, Ecosystems and Environment, 134, 19-23. https://doi.org/10.1016/j.agee.2009.06.016

[14] Lovett, G.M., Traynor, M.M., Pouyat, R.V., Carreiro, M.M., Zhu, W. and Baxter, J.W. (2000) Atmospheric Deposition to Oak Forests along an Urban-Rural Gra- 
dient. Environment Science and Technology, 34, 4294-4300.

https://doi.org/10.1021/es001077q

[15] Grimm, N.B., Faeth, S.H., Golubiewski, N.E., Redman, C.L., Wu, J.G., Bai, X.M., Briggs, J. and Golubiewski, N.E. (2008) Global Change and the Ecology of Cities. Science, 319, 756-760. https://doi.org/10.1126/science.1150195

[16] Lohsea, K.A., Hopea, D., Sponsellera, R., Allend, J.O. and Grimm, N.B. (2008) Atmospheric Deposition of Carbon and Nutrients across an Arid Metropolitan Area. Science of the Total Environment, 402, 95-105. https://doi.org/10.1016/j.scitotenv.2008.04.044

[17] Delmas, R.A., Loudjani, P., Podaire, A. and Menaut, J. (1991) Biomass Burning in Africa. In: Levine, J.S., Ed., Global Biomass Burning. Atmospheric, Climatic and Biospheric Implications, The MIT Press, Cambridge, 126-132.

[18] Hao, W.M. and Liu, M.H. (1994) Spatial and Temporal Distribution of Tropical Biomass Burning. Global Biogeochemical Cycles, 8, 495-503. https://doi.org/10.1029/94GB02086

[19] Tositti, L., Moroni, B., Dinelli, E., Morozzi, P., Brattich, E., Sebastiani, B., Petroselli, C., Crocchianti, S., Selvaggi, R., Enzo, G. and Cappelletti, D. (2020) Deposition Processes over Complex Topographies: Experimental Data Meets Atmospheric Modeling, Science of the Total Environment, 744, Article ID: 140974. https://doi.org/10.1016/j.scitotenv.2020.140974

[20] Guerrieri, R., Vanguelova, E., Pitman, R., Benham, S., Perks, M., Morison, J.I.L. and Mencuccini, M. (2020) Climate and Atmospheric Deposition Effects on Forest Water-Use Efficiency and Nitrogen Availability across Britain. Scientific Reports, 10, Article No. 12418. https://doi.org/10.1038/s41598-020-67562-w

[21] Langenberg, V.T., Nyamushahu, S., Roijackers, R. and Koelmans, A.A. (2003) External Nutrient Sources for Lake Tanganyika. Journal of Great Lakes Research, 29, 169-180. https://doi.org/10.1016/S0380-1330(03)70546-2

[22] Muvundja, A.F., Pasche, N., Bugenyi, W.B.F., Isumbisho, M., Müller, B., Namugize, J.N., Rinta, P., Schmid, M., Stierli, R. and Wüest, A. (2009) Balancing Nutrient Input to Lake Kivu. Journal of Great Lakes Research, 35, 406-418. https://doi.org/10.1016/j.jglr.2009.06.002

[23] Bagalwa, M., Majaliwa, J.G.M., Mushagalusa, N. and Karume, K. (2013) Estimation of Transported Pollutant Load from Small Urban Kahuwa River Micro-Catchment in Lake Kivu, Democratic Republic of Congo. Journal of Environment Science and Engineering B, 2, 460-472.

[24] Bagalwa, M., Majaliwa, M., Kansiime, F., Bootsma, H.A., Karume, K. and Mushagalusa, N. (2017) The Atmospheric Deposition of Phosphorus and Nitrogen on Lake Kivu. RUFORUM Working Document Series No. 14(2), 1159-1169.

[25] Ahn, H. and James, R.T. (2001) Variability, Uncertainty, and Sensitivity of Phosphorus Deposition Load Estimates in South Florida. Water Air Soil Pollution, 126, 37-51. https://doi.org/10.1023/A:1005235118716

[26] Schlesinger, W.H. (1997) Biogeochemistry: An Analysis of Global Change. Academic, San Diego, 588 p.

[27] Mahowald, N., Jickells, T.D., Baker, A.R., Artaxo, P., Benitez-Nelson, C.R., Bergametti, G., Bond, T.C., Chen, Y., Cohen, D.D., Herut, B., Kubilay, N., Losno, R., Luo, C., Maenhaut, W., McGee, K.A., Okin, G.S., Siefert, R.L. and Tsukuda, S. (2008) The Global Distribution of Atmospheric Phosphorus Deposition and Anthropogenic Impacts. Global Biogeochemical Cycle, 22, GB4026.

https://doi.org/10.1029/2008GB003240 
[28] Natacha, P., Muvundja, A.F., Schimid, M., Wuest, A. and Muller, B. (2012) Nutrient Cycling in Lake Kivu. In: Descy, J.P., Darchambeau, F. and Schimid, M., Eds., Lake Kivu: Limnology and Biogeochemistry of a Tropical Great Lake, Aquatic Ecology Series 5, Springer, Berlin, 31-46. https://doi.org/10.1007/978-94-007-4243-7_3

[29] Galloway, J.N., Aber, J.D., Erisman, J.W., Seitzinger, S.P., Howarth, R.W., Cowling, E.B. and Cosby, B.J. (2003) The Nitrogen Cascade. BioScience, 53, 341-356. https://doi.org/10.1641/0006-3568(2003)053[0341:TNC]2.0.CO;2

[30] Erisman, J.W., Bleeker, A., Galloway, J. and Sutton, M.A. (2007) Reduced Nitrogen in Ecology and the Environment. Environment Pollution, 150, 140-149. https://doi.org/10.1016/j.envpol.2007.06.033

[31] Zhang, Y., Wu, S.-Y., Hu, J., Krishnan, S., Wang, K., Queen, A., Aneja, V.P. and Arya, P. (2008) Modeling Agricultural Air Quality: Current Status, Major Challenges, and Outlook. Atmospheric Environment, 42, 3218-3237. https://doi.org/10.1016/j.atmosenv.2007.01.063

[32] Aneja, V.P., Schlesinger, W., Erisman, J.W., Behera, S.N., Sharma, M. and Battye, W. (2012) Reactive Nitrogen Emissions from Crop and Livestock Farming in India. Atmospheric Environment, 47, 92-103. https://doi.org/10.1016/j.atmosenv.2011.11.026

[33] Sims, L., Pastor, J., Lee, T. and Dewey, B. (2012) Nitrogen, Phosphorus and Light Effects on Growth and Allocation of Biomass and Nutrients in Wild Rice. Oecologia, 170, 65-76. https://doi.org/10.1007/s00442-012-2296-x

[34] Latzel, V., Klimešová, J., Hájek, T., Gómez, S. and Šmilauer, P. (2010) Maternal Effects Alter Progeny's Response to Disturbance and Nutrients in Two Plantago Species. Oikos, 119, 1700-1710. https://doi.org/10.1111/j.1600-0706.2010.18737.x

[35] Lasso, E. and Ackerman, J.D. (2013) Nutrient Limitation Restricts Growth and Reproductive Output in a Tropical Montane Cloud Forest Bromeliad: Findings from a Long-Term Forest Fertilization Experiment. Oecologia, 171, 165-174. https://doi.org/10.1007/s00442-012-2403-z

[36] LeBauer, D.S. and Treseder, K.K. (2008) Nitrogen Limitation of Net Primary Productivity in Terrestrial Ecosystems Is Globally Distributed. Ecology, 89, 371-379. https://doi.org/10.1890/06-2057.1

[37] Niu, S., Wu, M., Han, Y., Xia, J., Zhang, Z., Yang, H. and Wan, S. (2010) Nitrogen Effects on Net Ecosystem Carbon Exchange in a Temperate Steppe. Global Change Biology, 16, 144-155. https://doi.org/10.1111/j.1365-2486.2009.01894.x

[38] Bhattarai, S., Ross, K.A., Schmid, M., Anselmetti, F.S. and Bürgmann, H. (2012) Local Conditions Structure Unique Archaeal Communities in the Anoxic Sediments of Meromictic Lake Kivu. Microbial Ecology, 64, 291-300. https://doi.org/10.1007/s00248-012-0034-x

[39] Olapade, O.J. (2012) Anthropogenic Pollution Impact on Microbial Contamination of Lake Kivu, Rwanda. West African Journal of Applied Ecology, 20, 23-31.

[40] Schmid, M., Busbridge, M. and Wuest, A. (2010) Double-Diffusive Convection in Lake Kivu. Limnology and Oceanography, 55, 225-238. https://doi.org/10.4319/lo.2010.55.1.0225

[41] Borges, A.V., Abril, G., Delille, B., Descy, J.P. and Darchambeau, F. (2011) Diffusive Methane Emission to the Atmosphere from Lake Kivu (Eastern Africa). Journal of geophysical Research, 116, G03032. https://doi.org/10.1029/2011JG001673

[42] Maongo, T. (2007) Some Characteristics of Aftershock Sequences of Major Earthquakes from 1994 to 2002 in the Kivu Province, Western Rift Valley of Africa. Tectonophysics, 439, 1-12. https://doi.org/10.1016/j.tecto.2007.01.006 
[43] Muvundja, A. (2015) Hydrological Variability and Biogeochemistry of Particulate Organic Matter of a Large Tropical Rift Lake, Lake Kivu (East Africa). PhD Thesis, Universite de Namur, Belgique, 189 p.

[44] Bagalwa, M., Majaliwa, J.G.M., Kansiime, F., Bashwira, S., Tenywa, M. and Karume K. (2015) Sediment and Nutrient Loads into River Lwiro, in the Lake Kivu Basin, Democratic Republic of Congo. International Journal of Biological and Chemical Sciences, 9, 1678-1690. https://doi.org/10.4314/ijbcs.v9i3.46

[45] Bagalwa, M., Majaliwa, M.J.G., Kansiime, F., Bashwira, S., Tenywa, M., Karume, K. and Adipala, E. (2016) Land Use and Land Cover Change Detection in Rural Areas of River Lwiro Micro-Catchment, Lake Kivu, Democratic Republic of Congo. Journal of Scientific Research \& Reports, 9, 1-10. https://doi.org/10.9734/JSRR/2016/15850

[46] Anatolaki, Ch. and Tsitouridou, R. (2009) Relationship between Acidity and Ionic Composition of Wet Precipitation: A Two Years Study at an Urban Site, Thessaloniki, Greece. Atmospheric Research, 92, 100-113. https://doi.org/10.1016/j.atmosres.2008.09.008

[47] Anatolaki, Ch. and Tsitouridou, R. (2007) Atmospheric Deposition of Nitrogen, Sulfur and Chloride in Thessaloniki, Greece. Atmospheric Research, 85, 413-428. https://doi.org/10.1016/j.atmosres.2007.02.010

[48] APHA (American Public Health Association) (1989) Standard Methods for the Examination of Water and Wastewater. 18th Edition, Washington DC, 1587.

[49] Wetzel, R.G. and Likens, G.E. (2000) Limnological Analysis. Springer, Berlin, 429 p. https://doi.org/10.1007/978-1-4757-3250-4

[50] Bootsma, H.A. and Hecky, R.E. (1993) Conservation of the African Great Lakes: A Limnological Perspective. Conservation Biology, 7, 644-656.

https://doi.org/10.1046/j.1523-1739.1993.07030644.x

[51] Vuai, S.A.H., Ibembe, J.D. and Mungai, N.W. (2013) Influence of Land Use Activities on Spatial and Temporal Variation of Nutrient Deposition in Mwanza Region: Implication to the Atmospheric Loading to the Lake Victoria. Atmospheric and Climate Sciences, 3, 224-234. https://doi.org/10.4236/acs.2013.32024

[52] Bootsma, H.A., Mwita, J., Mwichande, B., Hecky, R.E., Kihedu, J. and Mwambungu, J. (1999) The Atmospheric Deposition of Nutrients on Lake Malawi/Nyassa. In: Bootsma, H.A. and Hecky, R.E., Eds., Water Quality Report, Lake Malawi/Nyassa Biodiversity Conservation Project, Southern Africa Development Community/Global Environmental Facility, 85-111.

[53] Mahowald, N.M., Artaxo, P., Baker, A.R., Jickells, T.D., Okin, G.S., Randerson, J.T. and Townsend, A.R. (2005) Impacts of Biomass Burning Emissions and Land Use Change on Amazonian Atmospheric Phosphorus Cycling and Deposition. Global Biogeochemistry Cycles, 19, GB4030. https://doi.org/10.1029/2005GB002541

[54] Graham, W.F. and Duce, R.A. (1979) Atmospheric Pathways of the Phosphorus Cycle. Geochimica et Cosmochimica Acta, 43, 1195-1208. https://doi.org/10.1016/0016-7037(79)90112-1

[55] Graham, W.F. and Duce, R.A. (1982) The Atmospheric Transport of Phosphorus to the Western North Atlantic. Atmospheric Environment, 16, 1089-1097. https://doi.org/10.1016/0004-6981(82)90198-6

[56] Kollher, S., Jungkunsi, H.F., Erasmi, S. and Gerold, G. (2013) The Effect of Land Use Change on Atmospheric Nutrient Deposition in Central Sulawesi. Erdkunde, 2, 109-122. https://doi.org/10.3112/erdkunde.2013.02.01

[57] Balagizi, M.C., Kasereka, M.M., Cuoco, E. and Liotta, M. (2018) Influence of Mois- 
ture Source Dynamics and Weather Patterns on Stable Isotopes Ratios of Precipitation in Central-Eastern Africa. Science of the Total Environment, 628-629, 1058-1078. https://doi.org/10.1016/j.scitotenv.2018.01.284

[58] Andreae, M.O. (1993) Global Distribution of Fires as Seen from Space. EOS, Transactions, American Geophysical Union, 74, 129-135.

https://doi.org/10.1029/93EO00166

[59] Behera, S.N., Sharma, M., Aneja, V.P. and Balasubramanian, R. (2013) Ammonia in the Atmosphere: A Review on Emission Sources, Atmospheric Chemistry and Deposition on Terrestrial Bodies. Environment Science Pollution Research, 20, 8092-8131. https://doi.org/10.1007/s11356-013-2051-9

[60] Cuoco, E., Spagnuolo, A., Balagizi, C., De Francesco, S., Tassi, F., Vaselli, O. and Tedesco, D. (2013) Impact of Volcanic Emissions on Rainwater Chemistry: The Case of Mt. Nyiragongo in the Virunga Volcanic Region (DRC). Journal of Geochemical Exploration, 125, 69-79. https://doi.org/10.1016/j.gexplo.2012.11.008

[61] Zirirane, N.D., Majaliwa, M.J.G., Muhigwa, B.J.B., Karume, K. and Bagalwa, M. (2014) Effet des flux d'eau sur la capacité de rétention des marais Ciranga et Kabamba, Lac Kivu, République Démocratique du Congo. Afrique SCIENCE, 10, 169-179. https://doi.org/10.4000/vertigo.16027

[62] Zirirane, N., Majaliwa, J.G.M., Muhigwa, B.J.B., Mushagalusa, N.G., Karume, K. and Bagalwa, M. (2015) Efficacité de rétention des polluants par les marais Ciranga et Kabamba du Lac Kivu, République Démocratique du Congo. VertigO-la revue électronique en sciences de Penvironnement, 15, 15 p. https://doi.org/10.4000/vertigo.16027

[63] Lacaux, J.P., Loemba-Ndembi, J., Lefeive, B., Cros, B. and Delmas, R. (1992) Biogenic Emissions and Biomass Burning Influences on the Chemistry of Fog Water and Stratiform Precipitation in the African Equatorial Forest. Atmospheric Environment $A$, 26, 541-551. https://doi.org/10.1016/0960-1686(92)90167-J

[64] Artaxo, P.R.C., Ferdinards, E.T., Martiens, J.V., Lindquist, O.F., Jimenez, M.T. and Maenhaut, W. (2000) Large Scale Mercury and Trace Element and Measurements in the Amazon Basin. Atmospheric Environment, 34, 4085-4096.

https://doi.org/10.1016/S1352-2310(00)00106-0 